\title{
Aumento das exposições aos agrotóxicos: contribuição da enfermagem
}

\author{
Increased exposures to pesticides: contribution of nursing
}

\author{
Elizabeth Regina de Melo Cabral' • Herling Gregório Aguilar Alonzo²
}

O Brasil é uma potência em agricultura. Há longo tempo, já se sabe que o uso de agrotóxico tem aumentado na agricultura brasileira devido à exploração inadequada dos solos e à aplicação de métodos produtivos defasados. Só em 2017, cerca de 540 mil toneladas de ingredientes ativos desses produtos foram consumidas ${ }^{(1)}$.

Em fevereiro de 2019, com a publicação no Diário Oficial, do ato n. ${ }^{\circ} 10$ da Coordenação-Geral de Agrotóxicos e Afins, que concede para o ano de 2019, mais de 29 registros de agrotóxicos. Junto com mais três atos semelhantes publicados em janeiro e fevereiro, deste mesmo ano, o total de registros de agrotóxicos concedidos já chega a 86 . De 2010 a 2016, os registros foram sempre abaixo de 20 por ano. Nos dois últimos anos o número subiu para 47 (2017) e 60 (2018), recorde em apenas 50 dias $^{(1)}$.

De acordo com dados pasta do Ministério da Agricultura, no período de 2015 a 2018 o número de registros autorizados cresceu na ordem de $220 \%$. E com estas liberações recentes, o país passou a contar com 2.123 agrotóxicos, se consolidando na liderança do ranking de um dos maiores consumidores de agrotóxicos do planeta ${ }^{(2)}$.

Desta forma, o governo mais uma vez se contradiz com o discurso de que novos agrotóxicos são menos perigosos, onde quase metade dos registros de hoje se enquadra na categoria extremamente tóxico ou altamente tóxico para o ser humano. Para esta classificação levasse em conta apenas os sintomas agudos provocados pelos agrotóxicos. Os sintomas crônicos, como o câncer, depressão e mutagênese não entram nesta avaliação. E os efeitos decorrentes da mistura entre agrotóxicos também são ignorados ${ }^{(3)}$.

Destes produtos extremamente tóxicos registrados atualmente, encontram-se o Glifosato, já proibido na França por seu potencial cancerígeno. E outro agrotóxico liberado recentemente é a base de 2,4-D. Nos seres humanos, esta molécula (o 2,4-D) causa alterações genéticas, malformações de embriões, neurotoxicidade, alterações hematológicas, distúrbios metabólicos e desregulação hormonal, além dos efeitos agudos ${ }^{(1,2)}$.

Essas aprovações vêm fomentando discussões na área da saúde, uma vez que expõe cada vez mais, não só os trabalhadores agrícolas, que lidam diretamente com as substâncias tóxicas no dia-a-dia de trabalho, mas também para toda população, que é exposta seja no alimento, na água ou no contato indireto desses produtos ${ }^{(3)}$.

As intoxicações por exposições aos agrotóxicos resultam em uma interação complexa entre as características do agrotóxico e a exposição ao produto. A exposição prolongada aos produtos agrotóxicos e ciclos de intoxicação aguda pode ocasionar uma intoxicação subaguda e crônica, com danos irreversíveis ${ }^{(2)}$.

Alguns agrotóxicos podem causar efeitos no desenvolvimento humano, como malformações fetais. Há estudos que apontam a exposição ambiental materna aos agrotóxicos foi associada a maior ocorrência de malformação fetal, em todos os trimestres da gestação. E ainda por cima, existem literaturas que associam a exposição ocupacional aos agrotóxicos do pai ou da mãe na ocorrência de malformação fetal ${ }^{(3)}$.

Fica evidente a forma de agressão à vida e ao meio ambiente, fortemente motivada por interesses econômicos, que envolve indústrias transnacionais, e com a garantia do governo de derramar no Brasil esses produtos.

A eficácia e efetividade das ações para proteger a saúde da população, depende da articulação em rede, onde os

'Enfermeira. Mestre e Doutroranda em Saúde Coletiva, pela Universidade Estadual de Campinas. Professora da Faculdade de Medicina São Leopoldo Mandic. Autor correspondente.

${ }^{2}$ Médico. Doutor em Saúde Coletiva. Professor Adjunto da Faculdade de Ciências Médicas, da Universidade Estadual de Campinas. 
processos e práticas interinstitucionais, multidisciplinares e participativas que incorporem informações de impactos sociais, ambientais e de saúde relacionados ao processo produtivo agropecuário e à exposição ocupacional, alimentar, ambiental e populacional aos agrotóxicos ${ }^{(2,3)}$.

Diante estes pontos, ressaltasse que a atuação de enfermeiros, devidamente capacitados para agir na prevenção, promoção, tratamento e reabilitação da saúde e na denúncia de fatores relacionados à aparição de doenças relacionadas a exposição aos agrotóxicos, é de suma importância para que se possam prestar as devidas orientações para a população. 


\section{REFERÊNCIAS}

I Campanha Permanente Contra os Agrotóxicos e Pela Vida [Internet]. Diário oficial venenoso:mais 29 agrotóxicos aprovados hoje. [acesso em 24 mar 2019]. Disponível em: http:// contraosagrotoxicos.org/diario-oficial-venenoso-mais-29-agrotoxicos-aprovados-hoje/

2 Carneiro FF, Rigotto RM, Augusto LGS, Friedrich K, Búrigo
AC, organizadores. Dossiê ABRASCO: um alerta sobre os impactos dos agrotóxicos na saúde. Rio de Janeiro: EPSJV, São Paulo: Expressão Popular, 2015.

3 Pignati WA, Souza e Lima FAN, Lara SS, Correa MLM, Barbosa JR, Leao LHC \& Pignati MG. Distribuição espacial do uso de agrotóxicos no Brasil: uma ferramenta para a Vigilância em Saúde. Ciência e Saúde coletiva. 2017; 22(10):328I-93. 